\title{
HIV Seropositivity among Patients Presenting with Herpes Zoster Infection
}

\author{
Abubaker Omer Ali Abdalla ${ }^{1 *}$, Isam Mohamed Elkhidir ${ }^{2}$ and Abdelgadir Ali Bashir ${ }^{3}$ \\ ${ }^{1}$ Educational Development Center, Faculty of Medicine, University of Khartoum, Khartoum, Sudan \\ ${ }^{2}$ Department of Microbiology, Faculty of Medicine, University of Khartoum, Khartoum, Sudan \\ ${ }^{3}$ Department of Community Medicine, Faculty of Medicine, University of Khartoum, Khartoum, Sudan
}

\begin{abstract}
Background: Skin manifestations are usually the first presentation in HIV infection. Most common of these manifestations is herpes zoster. This study was carried out to determine HIV seroprevalence in patients with herpes zoster and to identify factors that may affect its prevalence.

Methods: 40 patients were included in the study after clinical confirmation of herpes zoster. Every patient was interviewed privately to assess demographic, social and medical information. Data were obtained with high confidentiality. Blood samples were collected and tested for presence of antibodies against HIV.Khartoum.

Results: Out of the 40 patients screened, 6 (15\%) were found HIV seropositive, with significant association in patients with previous herpes zoster attack, history of traveling to endemic areas and sexually transmitted infections

Conclusion: We found high prevalence of HIV in patients with herpes zoster. These results may indicate the need for early screening of herpes zoster patients to facilitate better management of HIV infection.
\end{abstract}

Keywords: HIV; Seropositivity; Herpes zoster; Khartoum

\section{Introduction}

Skin manifestations are usually the first presentation in human immunodeficiency virus (HIV) infection, these manifestation may be the only sign of HIV infection in many cases [1]. Herpes zoster is the most common skin lesion in HIV patients. It results from activation of latent varicella zoster virus in dorsal root or cranial nerve ganglia after the primary infection of chickenpox. Herpes zoster presents as localized belt-like pain followed by vesicular skin rash in the affected area [2]. It is associated with depression of immunity, most importantly due HIV infection [3].

HIV infection is a global health problem that affects 33.3 million of people with 2.6 million new infections and 1.8 million deaths due to AIDs annually [4]. HIV infection has great impact on countries where it decreases life expediency of individuals and survival rate of children. In addition it has negative economic impact that leads to exhaustion of health care systems [5]. HIV control and management is a major challenge and one of the Millennium Developmental Goals that requires multidisciplinary involvement.

We carried out this study to determine HIV seroprevalence in patients with herpes zoster infection and to identify the factor that may affect its prevalence. Results from this study may help improve screening programs for early detection and efficient control of HIV infection that leads to a decrease in its related morbidity and mortality.

\section{Materials and Methods}

This study was carried out at Khartoum Dermatology Hospital in Khartoum city.

It is the largest dermatology hospital in Sudan, and attending physicians and specialists are available at the hospital.

This is a cross-sectional analytical hospital based study to determine HIV seropositivity among patients with herpes zoster presented at the clinic between March and September 2012. Inclusion criteria included all Patients who came to the outpatient clinic complaining of herpes zoster infection during the study period. Those who refused to participate were excluded from the study. Data were collected using a specially designed pretested close-ended questionnaire. Every patient was interviewed alone by the same trained personnel after obtaining consent to participate in the study. The questionnaire included questions about the demographic and social variables, in addition to questions on past medical history. Clinical examination was done as part of the routine examination at the clinic by a senior medical member, to confirm the diagnosis and determine the distribution of the rash. Blood samples were collected at the lab using Dried Blood Spot (DBS) technique [6] and were tested for presence of antibodies against HIV using ELISA technique [7] and confirmed by Western blot [8]. Data were collected and recorded with high level of confidentiality. Ethical approval for the study was obtained from the Hospital Research and Ethics Committee.

All collected data were analyzed using Statistical Package for Social Science (SPSS) version19 and Excel programs.

Descriptive frequencies were used to describe the distribution of variables while Chi-square and Fisher's exact tests were used to determine the significance of association with $95 \%$ confidence interval (P value $<0.05)$.

\section{Results}

A total of 40 patients were screened and $6(15 \%)$ were seropositive

*Corresponding author: Abubaker Omer Ali Abdalla, Educational Development Centre, Faculty of Medicine, University of Khartoum, Seifeldin st., Mamora, Khartoum, Sudan, Tel: +249999000811; E-mail: abubaker.omer@gmail.com

Received November12, 2014; Accepted December 27, 2014; Published January 10,2015

Citation: Abdalla AO, Elkhidir IM, Bashir AA (2015) HIV Seropositivity among Patients Presenting with Herpes Zoster Infection. J AIDS Clin Res 6: 413. doi:10.4172/2155-6113.1000413

Copyright: (c) 2015 Abdalla AO, et al. This is an open-access article distributed under the terms of the Creative Commons Attribution License, which permits unrestricted use, distribution, and reproduction in any medium, provided the original author and source are credited. 
Citation: Abdalla AO, Elkhidir IM, Bashir AA (2015) HIV Seropositivity among Patients Presenting with Herpes Zoster Infection. J AIDS Clin Res 6: 413. doi:10.4172/2155-6113.1000413

Page 2 of 3

for HIV. Of all HIV positive patients, 5 (83\%) were in the age group 25- 45 years and most of them were females residing in urban areas $(83 \%)$. All of them were sexually active and none of them used barrier methods during intercourse. 5 patients $(83 \%)$ had history of travelling to endemic areas of HIV and only 2 patients (33\%) had history of previous herpes zoster attack. Most patients had previous documented sexually transmitted diseases (67\%). The head was the most affected area (67\%) and only 2 cases (33\%) had multi dermatomal involvement (Tables 1-5).

\begin{tabular}{|c|c|c|c|}
\hline & & Frequency & Percent \\
\hline \multirow{3}{*}{ Age } & less than 25 years & 7 & $17.5 \%$ \\
\hline & $25-45$ years & 13 & $32.5 \%$ \\
\hline & more than 45 years & 20 & $50.0 \%$ \\
\hline \multirow{2}{*}{ Gender } & Male & 21 & $52.5 \%$ \\
\hline & Female & 19 & $47.5 \%$ \\
\hline \multirow{2}{*}{ Residency } & Khartoum & 24 & $60.0 \%$ \\
\hline & outside Khartoum & 16 & $40.0 \%$ \\
\hline \multirow{4}{*}{ Marital Status } & Single & 10 & $25.0 \%$ \\
\hline & Married & 28 & $70.0 \%$ \\
\hline & Divorced & 1 & $2.5 \%$ \\
\hline & Widow & 1 & $2.5 \%$ \\
\hline \multirow{4}{*}{ Educational Level } & Illiterate & 10 & $25.0 \%$ \\
\hline & primary school & 12 & $30.0 \%$ \\
\hline & secondary school & 12 & $30.0 \%$ \\
\hline & university and above & 6 & $15.0 \%$ \\
\hline
\end{tabular}

Half of the study samples were less than 45 years of age with $60 \%$ of them residing in Khartoum and $70 \%$ of them educated and married

Table 1: Frequency table showing the distribution of demographic characteristics in patients with herpes zoster at Khartoum Dermatology Hospital, 2012.

\begin{tabular}{|l|c|c|c|}
\hline \multirow{2}{*}{$\begin{array}{l}\text { Number of Sexual } \\
\text { Partners }\end{array}$} & Single & 22 & prequency \\
\cline { 2 - 4 } & Multiple & 7 & $55.0 \%$ \\
\hline \multirow{2}{*}{$\begin{array}{l}\text { Usage of Barrier } \\
\text { Methods (Condoms) }\end{array}$} & None & 11 & $17.5 \%$ \\
\hline \multirow{2}{*}{ Usage of Shared Lasers } & Yes & 0 & $.0 \%$ \\
\hline & Yes & 40 & $100.0 \%$ \\
\hline History of Travel to & No & 35 & $12.5 \%$ \\
\hline Endemic Area & Yes & 16 & $87.5 \%$ \\
\hline
\end{tabular}

$55 \%$ of the study sample had a single sexual partner and $40 \%$ with history of trave to endemic area while No one in the study sample had ever used condoms during sexual activity

Table 2: Frequency table showing the distribution of social parameters in patients with herpes zoster at Khartoum Dermatology Hospital, 2012.

\begin{tabular}{|l|c|c|c|}
\hline \multirow{2}{*}{$\begin{array}{l}\text { Current or Previous } \\
\text { Deblitating Condition }\end{array}$} & Yes & 13 & $32.5 \%$ \\
\hline \multirow{2}{*}{ Previous Attack } & No & 27 & $67.5 \%$ \\
\hline \multirow{2}{*}{$\begin{array}{l}\text { Previous Sexually } \\
\text { Transmitted Infection }\end{array}$} & Yes & 2 & $5.0 \%$ \\
\hline Previous Blood & No & 11 & $95.0 \%$ \\
\hline Transfusion & Yes & 29 & $27.5 \%$ \\
\hline Usage of & No & 39 & $72.5 \%$ \\
\hline Immunosuppressive Drugs & Yes & 4 & $2.5 \%$ \\
\cline { 2 - 4 } & No & 36 & $97.5 \%$ \\
\hline
\end{tabular}

$27.5 \%$ of patients had previous STIs while only a single patient in the study sample had a previous blood transfusion and only two patients suffered from previous herpes zoster attack

Table 3: Frequency table showing the distribution of past medical factors in patients with herpes zoster at Khartoum Dermatology Hospital, 2012

\begin{tabular}{|c|c|c|c|}
\hline \multicolumn{2}{|l|}{ Variables } & \multirow{2}{*}{$\begin{array}{c}\text { No. of positives } \\
0\end{array}$} & \multirow{2}{*}{\begin{tabular}{|c|} 
Percent \\
$0 \%$
\end{tabular}} \\
\hline \multirow{3}{*}{ Age } & less than 25 years & & \\
\hline & 25 - 45 years & 5 & $83 \%$ \\
\hline & more than 45 years & 1 & $17 \%$ \\
\hline \multirow{2}{*}{ Gender } & Male & 1 & $17 \%$ \\
\hline & Female & 5 & $83 \%$ \\
\hline \multirow{2}{*}{ Current Residency } & Khartoum & 5 & $83 \%$ \\
\hline & outside Khartoum & 1 & $17 \%$ \\
\hline \multirow{2}{*}{ Marital Status } & Single & 0 & $0 \%$ \\
\hline & Married & 6 & $100 \%$ \\
\hline \multirow{2}{*}{$\begin{array}{l}\text { USAGE OF BARRIER METHODS } \\
\text { (Condoms) }\end{array}$} & Yes & 0 & $0 \%$ \\
\hline & No & 6 & $100 \%$ \\
\hline \multirow{2}{*}{ History of Travel to Endemic Area } & Yes & 5 & $83 \%$ \\
\hline & No & 1 & $17 \%$ \\
\hline \multirow{2}{*}{ Previous Attack } & Yes & 2 & $33 \%$ \\
\hline & No & 4 & $67 \%$ \\
\hline \multirow{2}{*}{$\begin{array}{l}\text { Previous Sexually Transmitted } \\
\text { Infection }\end{array}$} & Yes & 4 & $67 \%$ \\
\hline & No & 2 & $33 \%$ \\
\hline \multirow{2}{*}{ Previous Needle Injections } & Yes & 1 & $17 \%$ \\
\hline & No & 5 & $83 \%$ \\
\hline \multirow{2}{*}{ Extend Of Dermatomal Involvement } & Single & 4 & $67 \%$ \\
\hline & Multiple & 2 & $33 \%$ \\
\hline
\end{tabular}

Table 4: Frequency table showing the Socio-demographic characteristics of 6 HIV seropositive patients at Khartoum Dermatology Hospital, 2012.

\begin{tabular}{|c|c|c|c|c|}
\hline \multicolumn{2}{|l|}{ Variables } & \multicolumn{2}{|c|}{ Test result } & \multirow{2}{*}{$\begin{array}{l}\text { Fisher's Exact } \\
P \text { value }\end{array}$} \\
\hline & & positive & negative & \\
\hline \multirow{2}{*}{ Current Residency } & Urban & 5 & 19 & \multirow{2}{*}{0.373} \\
\hline & Rural & 1 & 15 & \\
\hline \multirow{2}{*}{ Number of Sexual Partners } & Single & 3 & 30 & \multirow{2}{*}{0.055} \\
\hline & Multiple & 3 & 4 & \\
\hline \multirow{2}{*}{$\begin{array}{l}\text { History of Travel To Endemic } \\
\text { Area }\end{array}$} & Yes & 5 & 11 & \multirow{2}{*}{0.029} \\
\hline & No & 1 & 23 & \\
\hline \multirow{2}{*}{ Previous Attack } & Yes & 2 & 0 & \multirow{2}{*}{0.019} \\
\hline & No & 4 & 34 & \\
\hline \multirow{2}{*}{$\begin{array}{l}\text { Previous Sexually } \\
\text { Transmitted Infection }\end{array}$} & Yes & 4 & 7 & \multirow{2}{*}{0.039} \\
\hline & No & 2 & 27 & \\
\hline \multirow{2}{*}{$\begin{array}{l}\text { Extend of Dermatomal } \\
\text { Involvement }\end{array}$} & Single & 4 & 34 & \multirow{2}{*}{0.019} \\
\hline & Multiple & 2 & 0 & \\
\hline
\end{tabular}

Fisher's Exact Test showed significant $P$ value $(<0.05)$ with several variables

Table 5: Multiple cross-tabulation between the test results and the social and medical factors at Khartoum Dermatology Hospital, 2012.

\section{Discussion}

This study determined the prevalence and risk factors for HIV infection in patients with herpes zoster infection in a resource-limited setting in Sudan. The HIV prevalence was $15 \%$, this is in agreement with the prevalence in Nigeria [9], most likely attributed to the high prevalence of HIV in Africa. In contrast, studies conducted in India reported lower prevalence rates $[10,11]$. Similar to other studies $[11,12]$ most affected patients were in the age group 25-45 years, representing the most productive and sexually active individuals.

We found significant association between HIV seropositivity and patient with history of travelling to endemic areas $(\mathrm{P}=0.029)$, previous episode of herpes zoster infection $(\mathrm{P}=0.019)$, documented previous sexually transmitted infections $(\mathrm{P}=0.039)$ and multi-dermatomal involvement $(\mathrm{P}=0.019)$ as in different studies [10-12]. 
This study however found no statistically significant association between HIV infection and patients with multiple sexual partners $(\mathrm{P}=0.055)$. This may be due to religious and social barriers that prevent giving accurate information regarding sexual activities. In Sudan any sexual activity outside marriage is considered a crime punishable by low.

\section{Conclusion}

This study showed a high HIV prevalence in herpes zoster patients. Patients with herpes zoster should be counseled about risk factors for HIV infection and when appropriate, offered HIV screening test. This would facilitate better management of HIV infection that leads to a decrease in its related morbidity and improves the quality of life of HIVinfected patients.

\section{References}

1. National AIDS Control Organisation (2002) Skin and Mucocutaneous manifestations of HIV infection/AIDS. In: Specialistís Training and Reference module.71-81.

2. Katz J, Cooper EM, Walther RR, Sweeney EW, Dworkin RH (2004) Acute pain in herpes zoster and its impact on health-related quality of life. Clin Infect Dis 39: $342-348$

3. McCrary ML, Severson J, Trying SK (1999) Varicella zoster virus. J Am Acad Dermatol 41: 1-14.
4. UNAIDS (2010) UNAIDS report on the global AIDS epidemics 2010.

5. Gulick RM, Heath-Chiozzi M, Crumpacker CS (1990) Varicellazoster virus disease in patients with human immunodeficiency virus infection. Arch Dermatol 126: $1086-1088$

6. Sherman, Gayle G (2005) Dried Blood Spots Improve Access to HIV Diagnosis and Care for Infants in Low-Resource Settings. JAIDS 38: 615-617.

7. Dewar R, Goldstein D, Maldarelli F (2009) Diagnosis of human immunodeficiency virus infection. In: Mandell GL, Bennett GE, Dolin R (eds.) Mandell, Douglas, and Bennett's Principles and Practice of Infectious Diseases 1663-1686.

8. Renart J, Reiser J, Stark GR (1979) Transfer of proteins from gels to diazobenzyloxymethyl-paper and detection with antisera: a method for studying antibody specificity and antigen structure. Proceedings of the National Academy of Sciences USA 76: 3116-3120.

9. Adio AO, Fiebai B (2010) Herpes zoster ophthalmicus and HIV seropositivity in South-south Nigeria. Niger J Med 19:162-164.

10. Kar PK, Ramasastry CV (2003) HIV prevalence in patients with herpes zoster. Indian J Dermatol Venereol Leprol 69:116-119.

11. Jindal N, Aggarwal A, Kaur S (2009) HIV seroprevalence and HIV associated dermatoses among patients presenting with skin and mucocutaneaus disorders. Indian J Dermatol Venereol Leprol 75: 283-286.

12. Naburi AE, Barbara Leppard (2000) Herpes zoster and HIV infection in Tanzania. International Journal of STD \& AIDS 11: 254-256. 